\title{
EFFECTS OF TALENT MANAGEMENT, LEADERSHIP STYLE AND MOTIVATION ON EMPLOYEE PERFORMANCE IN INFORMATION TECHNOLOGY INDUSTRIES IN WEST JAKARTA AND WEST JAVA, INDONESIA
}

\author{
Supraptiningsih ${ }^{1}$, Otto Payangan ${ }^{2}$, Nurdin Brasit ${ }^{3}$ and \\ Ria Mardiana ${ }^{4}$ \\ Faculty of Economics and Business \\ University of Hasanuddin Makassar - Indonesia \\ DOI: $10.31364 / \mathrm{SCIRJ} / \mathrm{v} 6.111 .2018 . P 1118578$ \\ http://dx.doi.org/10.31364/SCIRJ/v6.i11.2018.P1118578
}

\begin{abstract}
In this globalization era, companies faced with many challenges to improve employees' performance. Of the many challenges, talent management is one of them. Due to this particular challenge, companies desperately need qualified workers. However, to get qualified workers is certainly not easy as they have to compete with other companies. The important of qualified workers for the company is partly to make the company's wheels to achieve optimally the desired goals, that is, to improve the effectiveness and efficiency of operations that can bring the organization to success. Talent management will greatly help the success of the desired goals by determining, finding, developing and managing and maintaining talented employees in an effort to achieve strategic goals and future business needs. This study, by using both primary and secondary data aims at examining effects of talent management, leadership style and motivation on the employees' performance of the Information technology industries in West Jakarta and West Java, Indonesia. This study found that talent management has significant effect on Employee Performance. Leadership Style influences Employee Performance and Motivation have significant influence toward Employee Performance. Also, Management Talent, Leadership Style and Talent Management Motivation have a positive and significant effect partially or simultaneously on Employee Performance. Thus, concern to these significant variables is a must for the information technology industries under surveyed in increasing their employees' performance.
\end{abstract}

Index terms- talent management, leadership style, motivation, employees' performance, Information technology industries.

\section{INTRODUCTION}

The business world today faced with many competitions not only for small and medium enterprises, but also for large scale businesses. The competition was not only limited in education business, but also in the business field of hospital, food and beverages, fashion and entertainment just to mention few business activities. All existing businesses are managed and placed in a company. Each company must have a description job that is useful for sorting out the types of work, where this job will be occupied or filled by people who should be reliable in their fields. By utilizing that the qualified workers , the desired results will be maximally obtained. Thus, the old statement that said 'the right man in the right place' is quite suitable to be noted by companies in selecting workers.

Talent Management is an investment. Every company wants to have the best and brightest employees. By having talent management it is expected that all employee goals can be achieved. According to Vance (2006), talent management in this context does not refer to the management of entertainers. However, it means as the strategic science of using Human resources to improve business value and make it possible for companies to reach their goals.

Not only by recruiting talented people, the company can adjust the business demands it faces, but it must also be considered the development factor of employees of talented people who already have it. This mean that by selecting, developing and retaining

\footnotetext{
${ }^{1} \mathrm{Ph}$. D candidate

${ }^{2}$ Professor of Economics

${ }^{3}$ Professor of Economics

${ }^{4}$ Senior Lecturer
} 
talented people companies can save a lot of money and make a profit in the form of continuous performance improvement. Thus, the main goal of talent management is to keep the best people, and keep them motivated.

This study aims at examining effects of talent management practice, leadership style and motivation on employee performance in the Information Technology industries in West Jakarta and West Java, Indonesia. However, before examining this objectives, section 2 review literatures to support this study. This is followed by the method of the study in section 3 . Section 4 discussed findings of the study. Finally, concluding remarks are drawn in section 5.

\section{LITERATURE REVIEW}

Definition of talent management is the recruitment, development and retention of individuals who consistently deliver superior performance.The aim is to employ people who consistently deliver superior performance. Talents are not limited to certain fields or levels of employees, but are available at all levels and functions (Davis, 2009).

The benefits of putting talent management as a strategic issue are as follows. First, the company will get people who have the ability to do a good job. Second, talented people can be developed to accept broader and larger responsibilities, and third, appointment and selection of talented people can be taken from internal sources.

The use of insiders will reduce the negative impact of appointments from outside people. One of the effects of the appointment of outsiders is that the person must start a new learning curve. However, the worse impact is that this action signals to employees that they are considered not good enough to have to take outsiders. The further impact is that internal employee motivation declining. Efforts to obtain, develop and retain internal employees who can contribute maximally to the company, that is called talent management.

Talent has become a hot topic in human resources management, and has a lot of interest by researchers and writers. The McKinsey company sparked such concern on year (1997) via providing information on talent (retention) to rethink the actions to be taken to attract the talented and their retention. In spite of the concept of talent, there was no clear definition of talent. Many studies that have addressed the issue of talent and talented people have a meaning to the term talent and the talented. However, there are clear differences between specialists and researchers regarding this field.

There are three main components of talent management, namely, talent attraction and selection, talent retention and talent management. According to Armstrong (2006) organization should use various techniques and methods for recruiting and selecting the right talent. The recruitment of talent pool is the first and important task of the talent management process. The talent pool is a group of candidates that are the potentials executive of the organization who will steer the organization towards the competitive performance. So to gain and maintain the performance of the organization, the recruitment and selection of the talented individuals is very crucial.

The creation of talent pool can be done in two forms, one is internal and second one is external. The internal recruitment of talent pool will be from the already existing employees of the organization. The internal recruitment may can give advantage as the employees already know the culture and way of doing work in the organization and it also might uplift the morale of the employees if their position is uplifted (Davis et al., 2007). However, the external sources will be the best way of gathering a talent when organization wants to bring the cultural change and wants innovation (Ballesteros \& Inmaculada, 2010). Employer branding includes development of an organization's image, is good enough to attract employees. Without the good brand image, it is difficult to attract the right talents (Ana, 2009).

Unlike talent attraction and selection, talent retention is a process of retaining the talented employees with the organization for a longer time period of time. The turn of talent from any organizations very harmful as is cause a reduction in the productivity of the organization as well as more cost to attract the new pool of talent (Echols, 2007). There two classification of retention the talented employees with organization, namely intrinsic incentives and extrinsic incentives. Intrinsic incentive includes some non monetary rewards that can satisfy employee's psychological needs while the extrinsic rewards are the monetary rewards which may help to fulfill employee's physiological needs. The monetary reward is admitted as an essential tool to retaining talent (Vaiman \& Vance, 2008). Furthermore, organization needs to invest more for the purpose of retaining the employees with organization, a good rewards system important to attract, and retain the talent with organization. This can motivate the employees, resulting in high performance of the organization (Mendez \& Stander, 2011).

In regard with talent development, it is defined talent development as the process of upgrading the skills and attitude of the employees. As the business continuously keep on changing the technologies business models and new strategies to cope up with these changes, organization needs to enhance and upgrade the knowledge of the employees. While making strategies for development, practitioners must keep in mind the integration and strategic fit between the current talent and the skills of the employees. 
It should be noted that the major goal of every organizational strategy is to enhance the effectiveness and efficiency of the operation which could lead the organization to success. Talent Management is essential when the organizations will like to build winning teams which will be formed by talented personnel. The organization will use these kinds of teams to solve and determinate problems or weaknesses in departments. For example, if there is a trouble in the Financial Department, the organization will build a team to solve this problem and they are going to solve it, because they are competent and experienced people in this field (Davis et al., 2007).

The studies show that if the organizational strategies and technology would be complex, its key success is human factor. Therefore, managers should consider to the factors which effect on organizational success. In this regard, Lewis \& Heckman (2006) identified three key streams of analyzing the effectiveness of talent management practices. A first stream refers to an analytical technique to tie talent management to financial performance. A second stream emphasizes the process of analyzing and optimizing the talent management system, and authors aligned. The third stream appear to see analytics as a set of metrics and measures for use by different users.

Considering a financial perspective, researchers assess the relationship between competences in talent management and financial organizational performance and demonstrate why talent management is a worthwhile investment. Organizations that apply talent management practices demonstrate significantly higher financial performance compared to their industry's peers. The financial performance can be measured from sales revenue and productivity, Net Profit Margin and Earnings Before Interest, Depreciation, and Amortization (EBITDA), Return on Assets and Return on Equity, or Return on Shareholders' value and Market Value. Moreover, different studies induce talent management cost savings through long-term proactive internal succession planning and higher retention rates.

According to the research conducted by Carlucci et al. (2004) explored that business performance can also be influenced by managing talent assets. It is also researched that there is the huge role of value generated for the key stakeholders with the business performance in an organization. It is also researched that organizational processes are based on some competencies which is used to manage the business effectively and efficiently. The generated value has the huge role to manage the business process.

Finally organizational competencies are developed and processed by the management of talent assets in an organization. Hence it has been cleared organizational competencies are the result of effective and efficient management of talent assets that increases the business performance and value creation. In the same way the effectiveness of talent asset management will provide firms the skills to align the demand of market with talent resources (Zott, 2003). Dynamic capabilities are used by the firm to achieve new resource configurations as markets evolve, emerge, evolve die. Dynamics capabilities are more useful to individual firms to gain sustainable competitive advantage and long term superior performance (Teece et al., 1997).

It has been argued from the previous studies that talent management practices has the huge role to compete in the market and have competitive advantage on others. It is also explored that organization can gain only short span of time competitive advantage with the help of innovations and new technologies. It is the only talent management practice which gives the sustained competitive advantage in the market by organization attraction, development, motivation, management and reward the talent (Heimen \& Colleen, 2004). Like a machine, a business will fail to operate successfully if key elements such as processes, systems, and structure are misaligned or hindered by friction between those element and like a machine, a business must be designed, operated, and maintained. These functions are performed by the talent - the human capital employed by the enterprise.

Indeed, talent (i.e., an organization's employees), typically is the single biggest lever for driving improvements in business performance. The collective skills of the talent employed in an organization largely comprise the organization's core capabilities. An organization's talent injects capabilities that are very difficult for competitors to benchmark and replicate. More than any other asset, talent provides the potential for long-term competitive advantage (Lawler, 2008).

Furthermore, management study conducted by the Boston Consulting Group (2008) on several continents found the following things: First, talented employees and leadership will become increasingly scarce resources. the workforce will on average get older and now people tend to have fewer children. Second, the company will move into a global organization. Third, the emotional needs of employees will be more important than ever. Another interesting data relating to talent management is done by McKinsey (2001 ). He found the following interesting things. First, the growth of the company is limited because there are not enough talented employees. Second, it is because the company lacks talented leaders. Third, in five years, the average company will lose $30 \%$ of its executive staff. Fourth, high error rate (40-50\%) when talented executive employees are hijacked from outside the company. Fifth, two-thirds of employees have a low level of trust until they are top leaders. Three-quarters of their executives also said the same. Sixth, employees state that corporate leadership is a major factor in job satisfaction, commitment and retention factors in the company. Seventh, employees most appreciate the quality of honesty and integrity in leaders. Eight, only one percent of companies that state succession in their companies are very good, while two-thirds of them declare bad or ordinary.

Finally, the Boston Consulting Model suggests that there are five important elements that are mutually integrated in people management that need to be considered in the regulation of talents. Starting from employee planning, until the effort to 
make employees remain committed to being part of the company ( see, Accenture, 2007). This model illustrates the relationship between the concept of talent management and the surrounding work environment. Business strategies as outlined in the talent strategy will be input into the cycle of talented employees (define-discover-develop-deploy) and produce employee performance output that results in business results. See Accenture (2007) for details.

In terms of leadership style, Tadad, Terry, Hoyt (in Kartono, 2003) define leadership namely activity or art influences other people to cooperate which is based on the person's ability to guide others in achieving the desired goals of the group. According to Young (in Kartono, 2003) Definition of Leadership is a form of domination that is based on personal abilities that are able to encourage or invite others to do something based on acceptance by the group, and have special expertise in the field desired by the group to achieve organizational or group goals While Stephen p . Robbins and Mary Coulter (2004, p 146) define leaders are people who can influence others and have managerial authority. Whereas Leadership is what leaders do. Leadership is the process of leading a group and influencing the group in achieving its goals. From the above definition it can be concluded that leadership is the ability to influence other people, subordinates or groups, the ability to direct subordinate or group behavior, have special abilities or expertise in the field desired by the group, to achieve organizational or group goals.

Furthermore, motivation is important to make employees provide maximum work effort. For this reason managers need to know how and why they are motivated. Of the many duties of the leadership is to provide encouragement or motivation to employees or subordinates to work in accordance with what is expected. According to Stephen p. Robbins and Mary Coulter (2004), the notion of motivation refers to the process in which one's efforts are energized, directed and sustained towards achieving a goal. Whereas Robbins and Judge (2007) defines motivation as a process that explains intensity, direction and persistence of business to achieve a goal. However, Samsudin, (2005) defines motivation as a process of influencing or encouraging from outside to someone or a work group so that they want to implement something that has been set. Motivation can also be interpreted as a driving force intended as a natural urge to satisfy and sustain life. Mangkunegara (2005.61) states: "motivation is formed from the attitude (attitude) of employees in facing work situations in the company (situation). Motivation is a condition or energy that directs employees who are directed or aimed at achieving the goals of the company's organization. The mental attitude of employees who are pro and positive towards work situations is what strengthens their work motivation to achieve maximum performance.

The above variables have been argued affecting performance of employees. According to Bernardin and Russel in Sulistiyani $(2003,223-224)$ states that performance is a record of outcomes resulting from certain employee functions or activities carried out during a certain period of time. Simamora (1997) suggests that employee performance is the level at which employees achieve job requirements. While Suprihanto (in Srimulyo, 1999: 33) says that the performance or performance of an employee is basically the work of someone during a certain period of time compared to the possibility, for example standards, targets or targets that have been predetermined and agreed upon. Performance refers to employee performance measured by the standards or criteria set by the company. The definition of performance or work performance is given a limit by Maier (in Moh As'ad, 2003) as someone's success in carrying out a job. More explicitly Lawler and Poter stated that performance is a "successful role achievement" obtained by someone from his actions (Moh As'ad, 2003).

\section{HYPOTHESIS AND METHODS}

There are seven hypothesis of the study that need to be tested. First, there is an influence between talent management on employee performance. Second, there is an influence between leadership style on employee performance. Third, there is an influence between motivation on employee performance. Fourth, there is an influence between talent management on leadership style. Fifth, there is an influence between talent management and motivation. Sixth, there is an influence between talent management, leadership style and motivation on employee performance. Finally, it is hypothesized that there is an influence between leadership style and motivation.

Method to test the above hypothesis is by using the Structural Equation Model with Confirmatory Factor Analysis (CFA) using the AMOS 25.0 program. The predictive power of observation variables both at the individual level and at the construct level is seen through Critical Ratio (CR). If the Critical Ratio is significant, the indicators will be said to be useful for predicting constructs or latent variables.

The construct variable of this study consists of talent management, leadership style, work motivation and employee performance. By using the structural equation model from AMOS there will be model indicators that are fit. The benchmark used in testing each hypothesis is the value of the critical ratio (CT) at the regression weight with a minimum value of 1.960 in absolute terms.

of:

The criteria used are to test whether the proposed model is compatible with the data or not. The model fit criteria consist

1) the degree of freedom must be positive;

2) the non-significant Chi-square required ( $\mathrm{p} £ 0.05)$ and above the conservative accepted $(\mathrm{p}=0.10)(\mathrm{Hair}$ et al., 2006), 
3) 3) incremental fit above 0.90 namely (GFI) (goodness of Fit Index), Adjusted GFI (AGFI), Tucker Lewis Index (TLI), The Minimum Sample Discrepancy Function (CMIN) divided by Degree of Freedom (DF) and Comparative Fit Index (CFI), and

4) Low RMSEA (Root Mean Square Error of Approximation).

Note that, confirmatory factor analysis is used to examine latent variables that cannot be measured directly. Analysis of the indicators used gives meaning to latent variables or constructs that are confirmed. The results of the analysis is discussed in the following section 4 .

\section{RESULTS AND DISCUSSION}

As exhibits at Table 1, the results of hypothesis testing can be summarized as follows. First, the H1 hypothesis is accepted. It is based on (i) the estimated value of the coefficient of $0.274>0$. This states that the causal relationship is positive. (ii) the critical value of 5,443 is greater than the limit of 1.96 for the confidence level of 0.05 , and (iii) the value of $\mathrm{p}$-value 0,000 . This indicates that increasing talent management will improve employee performance. Thus there is no doubt to accept that talent management has a positive and significant effect on employee performance.

Table 1.Results of hypothesis testing

\begin{tabular}{|l|l|l|l|l|l|l|}
\hline Hypotheses & $\begin{array}{l}\text { Independent } \\
\text { Variables }\end{array}$ & $\begin{array}{l}\text { Dependent } \\
\text { variable }\end{array}$ & Standardized & C.R & P-values & Notes \\
\hline H1 & $\begin{array}{l}\text { Talent } \\
\text { Management }\end{array}$ & $\begin{array}{l}\text { Employee } \\
\text { performance }\end{array}$ & 0.274 & 5.443 & 0.000 & Accepted \\
\hline H2 & $\begin{array}{l}\text { Talent } \\
\text { management }\end{array}$ & $\begin{array}{l}\text { Leadership } \\
\text { style }\end{array}$ & 0.684 & 9.287 & 0.000 & Accepted \\
\hline H3 & $\begin{array}{l}\text { Talent } \\
\text { Management }\end{array}$ & $\begin{array}{l}\text { Work } \\
\text { Motivation }\end{array}$ & 0.487 & 8.309 & 0.000 & Accepted \\
\hline H4 & $\begin{array}{l}\text { Leadership } \\
\text { style }\end{array}$ & $\begin{array}{l}\text { Employees' } \\
\text { performance }\end{array}$ & 0.200 & 2.433 & 0.015 & accepted \\
\hline H5 & $\begin{array}{l}\text { Leadership } \\
\text { style }\end{array}$ & $\begin{array}{l}\text { Work } \\
\text { Motivation }\end{array}$ & 0.796 & 7.997 & 0.000 & accepted \\
\hline H6 & $\begin{array}{l}\text { Work } \\
\text { Motivation }\end{array}$ & $\begin{array}{l}\text { Employees' } \\
\text { performance }\end{array}$ & 0.539 & 5.656 & 0.000 & accepted \\
\hline H7 & $\begin{array}{l}\text { Work } \\
\text { Motivation }\end{array}$ & $\begin{array}{l}\text { Leadership } \\
\text { style }\end{array}$ & 0.717 & 9.070 & 0.000 & accepted \\
\hline
\end{tabular}

Source : estimated from the data.

Second, the H2 hypothesis is also accepted. This is based on (i) the estimated value of the coefficient of $0.684>0$. This shows that the causal relationship is positive. (ii) the critical value of 9,287 is greater than the limit of 1.96 for the confidence level of 0.05 , and (iii) the p-value of 0,000. This suggests that the increase in talent management will improve the leadership style. Thus there is no doubt to accept that talent management has a positive and significant effect on leadership style.

Third, the H3 hypothesis is accepted. This is based on (i) the estimated value of the coefficient of $0.487>0$ which means that the causal relationship is positive; (ii) the critical value of 8.309 is greater than the 1.96 limit for the 0.05 level of confidence, and (iii) the p-value of 0.000 . Again this indicates that increasing talent management will increase employee motivation. Thus there is no doubt to accept that talent management has a positive and significant effect on employee motivation.

Fourth, the H4 hypothesis is accepted. This shows from (i) the estimated value of the coefficient of $0.200>0$ which states that the causal relationship is positive; (ii) the critical value of 2,433 is greater than the limit of 1.96 for the confidence level of 0.05 , and (iii) the p-value of 0.015 . These suggest that by increasing the leadership style it will improve employee performance. Thus, the leadership style has a positive and significant effect on employee performance.

Fifth, the H5 hypothesis is accepted. This is shown from (i) the estimated value of the coefficient of $0.796>0$ which suggests that the causal relationship is positive; (ii) the critical value of 7.997 is greater than the limit of 1.96 for the confidence level of 0.05 , and (iii) the p-value of 0.000 . This indicates that by increasing the leadership style it will increase work motivation. Thus, leadership styles have a positive and significant effect on work motivation.

Sixth, the H6 hypothesis is also accepted. This is because (i) the estimated value of the coefficient is $0.539>0$, which states that the causal relationship is positive; (ii) the critical value of 5.656 is greater than the 1.96 limit for the 0.05 level of confidence, and (iii) the p-value of 0.000 . This indicates that by increasing work motivation it will improve employee performance. Thus, work motivation has a positive and significant effect on employee performance. 
The $\mathrm{H} 7$ hypothesis is also accepted since (i) the estimated value of the coefficient of 0.717 which states that the causal relationship is positive; (ii) the critical value of 9,070 is greater than the limit of 1.96 for the confidence level of 0.05 , and (iii) the value of p-value 0,000 . This indicates that increasing work motivation will improve leadership style. Thus there is no doubt that work motivation has a positive and significant effect on leadership style.

In terms of the path analysis, as can be seen at Table 2 the direct influence of talent Management variables on Work Motivation of 0.478 and indirect effects of Talent Management on Work Motivation through Leadership and Motivation Style Work of 0.796. On the direct influence of the Leadership Style variable on Employee Performance of 0.200 and the indirect influence of the Leadership Style on Employee Performance through Work Motivation of 0.298.

Table 2. Results of Path analysis of Structural Model

\begin{tabular}{|l|l|l|l|l|l|}
\hline No & $\begin{array}{l}\text { Independent Variable } \\
(\mathrm{A})\end{array}$ & $\begin{array}{l}\text { Dependent } \\
\text { Variable } \\
(\mathrm{B})\end{array}$ & $\begin{array}{l}\text { Intervening } \\
\text { Variable } \\
(\mathrm{C})\end{array}$ & $\begin{array}{l}\text { Direct Effect } \\
\text { (A-B) }\end{array}$ & $\begin{array}{l}\text { Indirect Effect } \\
(\text { A-C-.B })\end{array}$ \\
\hline 1 & Talent Management & $\begin{array}{l}\text { Employees' } \\
\text { Performance }\end{array}$ & $\begin{array}{l}\text { Leadership style } \\
\text { and work } \\
\text { motivation }\end{array}$ & 0.274 & 0.796 \\
\hline 2 & Talent management & Leadership Style & & 0.684 & 0.571 \\
\hline 3 & Talent Management & Work motivation & Leadership style & 0.487 & 0.298 \\
\hline 5 & Leadership style & $\begin{array}{l}\text { Employees' } \\
\text { performance }\end{array}$ & $\begin{array}{l}\text { Work } \\
\text { Motivation }\end{array}$ & 0.200 & 0.796 \\
\hline 6 & Leadership style & Work Motivation & & 0.539 & \\
\hline
\end{tabular}

Source : Estimated from the data collected in the survey.

\section{CONCLUSION}

This study found that talent management has significant effect on Employee Performance. Leadership Style influences Employee Performance and Motivation have significant influence toward Employee Performance. Also, Management Talent, Leadership Style and Talent Management Motivation have a positive and significant effect partially or simultaneously on Employee Performance. Thus, concern to these significant variables is a must for the information technology industries under surveyed in increasing their employees' performance.

\section{REFERENCES}

Andy Gazly Satria Amal, Usulan Penelitian Disertasi, Knowledge Management (KM): Hubungan Antara Elemen-Elemen Organisasi Terhadap Kinerja Kowledge Transfer Pada International Crime Police Organisation (ICPO) NCB-Interpol Indonesia, 2014, Program Doktor Ilmu Ekonomi, Fakultas Ekonomi dan Bisnis, Universitas Hasanuddin, Makassar.

Accenture (2007), Talent Management, Accenture Point of View , Florida: Human Performance Roundtable.

Arif Kamisan, P1 \& Brian E.M. King, 2013, Transactional and Tranformational Leadership : A Comparative Study of the Difference between Tony Fernandes (Airasia) and Idris Jala (Malaysia Airlines) Leadership Styles from 2005 - 2009.

School of Hotel and Tourism Management, The Hong Kong Polytechic University, Hong Kong, China.

Berger, L \& Berger, D. R.. (2004), Talent Management Handbook, New York, Mc-Graw- Hill

Bennet, M \& Bell, A. (2004) Leadership Talent in Asia New Jersey, Joh Wiley \& Sons

Bennett N.B. Silalahi, M.A., Perencanaan Pembinaan Tenaga Kerja Perusahaan, 1983, Penerbit PT Pustaka Binaman Pressindo.

Cheese, P, Thomas, R.J. \& Craig, E. (2007) The Talent Powered Organization Strategies for Globalization, Talent Management and High Performance, London \& Philadelphia: Kogan Page Publisher.

Faria Rabbi SEGI University Malaysia, Malaysia, Talent management as a source of competitive advantage. Journal of Asian Business Strategy. Nouman Ahad, Tahira Kousar and Tanzila Ali GC. University Faisalabad, Sahiwal Campus, Pakistan.

G. P. Mishra, Donald grunewald \& Neelufer Aslam Kulkarni, 2014, “ Leadership styles of Senior and Middle Level Managers: A Study of Selected Firms in Muscat, Sultanate of Oman. Departement of Management, Waljat College of Applied Science, Muscat, sultanate of Oman. Departement of Strategic Management, Iona College, New York, U.S.A.

Mandana Abdizadeh \& Mohsen Malekalketab Khiabani, 2014, Implementing the Spiritual Leadership Model in the Healthcare Industry in Iran. International business school, University technology Malaysia, Malaysia.

Merriam - Webster, An encyclopedia, Britannica Company

Mahdieh Koupahi, Kamran pashaei Fakhri, Peyman Ghanimat, 2013, Journal of Basic and Applied Scientific Research, "The Relationship Between Learning and Organizational Performance”. 
Martinsons, M.G., City University of Hong Kong, Kowloon, Hong Kong, China, 1997, International Journal of Human Resources Management, Comparing The Decision Styles Of American, Japanese And Chinese Business Leaders.

Moh As'ad 2003, Psikologi Industri, Yogyakarta: Libery

Pekka Aula' \& Kalle Siira, 1999, International Journal of Management, Organizational Communication and Conflict Management Systems, A Social Complexity Approach.

Moeheriono, Pengukuran Kinerja Berbasis Kompetensi, 2012, PT RajaGrafindo Persada, Jakarta.

Richard et al. 92009) : Measuring Organizational Performance: Towards Methodological Best Practice, Journal of Management, Vol. 35. Nr. 5. Pp. $718-804$.

Robert L. Mathis - John H. Jackson, 2006, Human Resource Management, Edisi ke 10, Penerbit Salemba Empat.

Salah M. Diab, 2014, The Impact of Leadership styles on Selection the Areas of Organizational Change (An Empirical Study on the Jordanian Pharmaceutical Companies). Business Administration Department, Economics and Admin. Faculty, Applied Science University, Amman, Jordan.

Seher Arikan Tezeergil, 2014, Ali Kose \& Melisa Erdilek Karabay, Investigating the Effect of Trust, Work-Involvement, Motivation and Demographic Variables on Organizational Commitment: Evidence from IT Industry. School of Banking and Insurance, Marmara University, Istanbul, Turkey.

Sukono Soebekti, Rama Royani, Nina Insania K. Permana, 2010, Memanfaatkan Bakat untuk Sukses, 4E ( Enjoy, Easy, Excellent, Earn), Penerbit PPM, Jakarta.

Stephen P. Robbins (San diego State University), Mary Counlter (Mosspiro state University), Manajemen, edisi ke sepuluh, jilid 1,2004

Simamora, Henry, 1997, Manajemen Sumber Daya Manusia Edisi Kedua STIE YKPN

Syarifuddin,. Darwis Said, Ratna Ayu Damayanti, Indrianty Sudirman, Yohanis Rura, Yansor Djaya Grace T. Pontoh, Sanusi Fattah, Mursalim Nohong, Pedoman Penulisan Tesis dan Disertasi, 2013, Penerbit Fakultas Ekonomi dan Bisnis Universitas Hasanuddin, Jl. Perintis Kemerdekaan Km. 10 Tamalanrea, Makassar 90245.

Tika, p. 2006 Budaya Organisasi Dan Peningkatan Kinerja Perusahaan. PT Bumi Aksara, Jakarta.

Tony Davis, Maggie Cut, Neil Flynn, Peter Mowl, Simon Orme, 2009, Talent Assessment, Mengukur, Menilai dan Menyeleksi Orang-Orang Terbaik dalam Perusahaan, Penerbit PPM, Jakarta.

Taufik Bahaudin, 1998, BrainWare Management, Generasi Kelima Manajemen Manusia, Memenangkan' Knowledge to Knowledge Competition, Menyongsong Era Millenium. 